\title{
Technical Evaluation of Battery Electric Bus Potential in Mexico City and Leon, Mexico
}

Clean, advanced vehicle technologies, such as battery electric buses (BEBs), can contribute to fewer traffic emissions, improved air quality and public health, economic development opportunities, and a better quality of life for city inhabitants. Globally, the BEB is the fastest growing form of electrified transportation, as public transit in dense cities is key to traffic congestion reduction and air quality improvements, with significant BEB deployment in China (IEA 2020). Projected technology cost declines are expected to drive BEB sales to $84 \%$ of all transit bus sales by 2030 (BNEF 2018).

Several factors contribute to BEB market growth. For one, BEBs are 3-4 times more efficient on an energy basis (i.e., joule of energy) than their conventional counterparts (Eudy et al. 2016). Moreover, they typically have lower fuel and maintenance costs than conventional vehicles. In fact, the total cost of ownership of BEBs can be competitive with conventional buses when purchase subsidies are included to offset high capital costs (BNEF 2020). Third, BEBs produce fewer (or displace) emissions that contribute to local air pollution harmful to human health and greenhouse gas emissions that contribute to climate change. Despite these advantages, barriers such as high upfront costs, reduced range and charging convenience, less vehicle variety, and general unfamiliarity in the field can hinder BEB deployment. The exact benefits and barriers to BEB deployment depend on their application and implementation; it is not as simple as buying BEBs to replace conventional municipal buses. As with other advanced

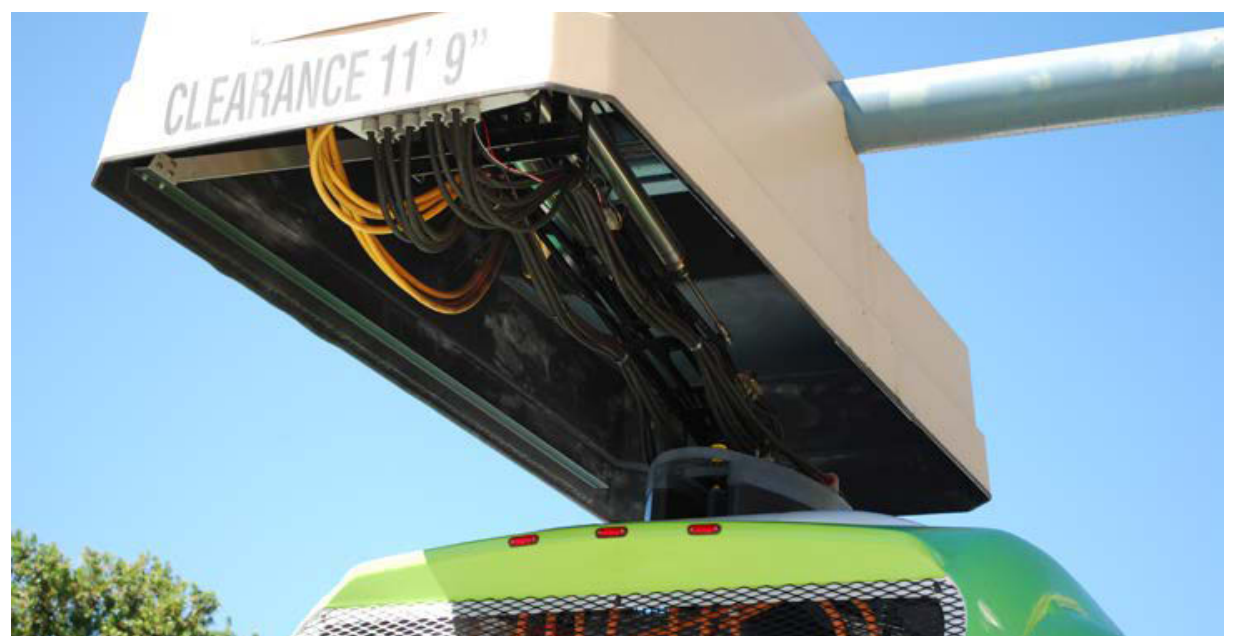

Figure 1. Proterra fast-charge electric bus charging station photo by: Leslie Eudy, NREL

energy technologies, BEB deployment requires addressing technological, financial, and institutional barriers.

Mexico is one of many countries weighing the benefits of BEBs and how they can contribute to transportation, energy, and climate goals. In 2013, Mexico's transport sector produced $26.2 \%$ of national greenhouse gas emissions, according to Mexico's Biennial Update Report to the United Nations Framework Convention on Climate Change (UNFCCC) submitted in 2015 (Gobierno de la República de México 2015). As such, transportation is a key sector included in Mexico's Intended Nationally Determined Contribution (2015), which commits Mexico to a $22 \%$ reduction in greenhouse gases and short-lived pollutants by 2030. Mexico's Ministry of Environment (SEMARNAT) has highlighted clean energy use and adoption in the transport sector as a priority in its National Air Quality Strategy (Secretaría de Medio Ambiente y Recursos Naturales de México 2017). Moreover, municipalities in Mexico are also recognizing the importance of adopting clean energy technologies in the transport sector to improve local air quality and reduce carbon emissions. In 2017, Mexico City's Mayor (at the time) José Ramón Amieva joined eleven other mayors from global cities in a pledge to purchase only zero-emission buses as of 2025 (C40 Cities). Bus electrification can serve as a critical tool in accomplishing Mexico's low emissions development goals, particularly in urban areas.

Against this backdrop, the National Renewable Energy Laboratory (NREL), in partnership with USAID Mexico's Low Emissions Development (MLED) II program and Mexican transportation stakeholders, set out to explore the technical feasibility of transit bus electrification in CDMX (i.e., Mexico City) and León, Mexico, detailed below. 


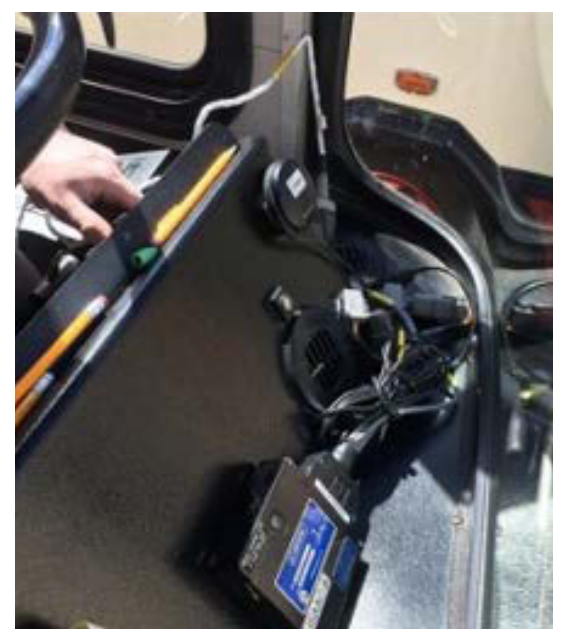

Figure 2. Example of a data logger placed on a bus. Photo credit: NREL

\section{Technical Analysis Overview}

\section{Research Question}

What is the potential for transit bus electrification (via BEBs) in Mexico City and León, Mexico?

\section{Data Collection and Methods}

NREL and USAID engaged CDMX and León transit agencies to understand bus routes of interest for electrification and characteristics of existing fleets. Using specialized data loggers and GPS, NREL tracked key vehicle information of operating diesel buses such as speed, distance traveled, and frequency of stops along one bus route in CDMX and two routes in León over a 2-4 week period in September and October 2017 (Table 1). Additionally, NREL worked with bus depot managers to collect information on bus fueling, age, emissions, wheel design for rolling resistance, and capacity (i.e., weight or number of passengers).
Using the Future Automotive Systems Technology Simulator (FASTSim) model and vehicle information from the data loggers and bus depot records, NREL analyzed the energy consumption and fuel economy (i.e., efficiency) of conventional diesel buses and battery electric alternatives given the conditions (e.g., speed, distance, number of stops) of the specific routes in CDMX and León. Energy consumption informed the battery size needed to complete these specific routes if BEBs were used instead of diesel. To address interest in air quality and emissions, NREL compared fuel and electricity production emissions of battery electric and diesel buses using Argonne National Lab's Greenhouse Gases, Regulated Emissions, and Energy Use in Transportation (GREET) model.

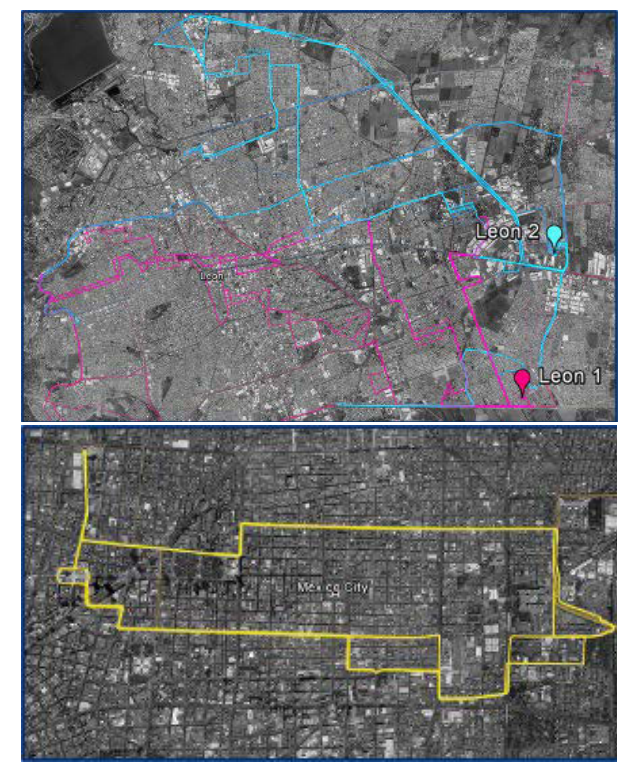

Figures 3-4. The bus routes modeled in Mexico City (yellow) and León (pink and blue) @2020 Google Earth

\begin{tabular}{|c|c|c|c|c|c|c|}
\hline Depot & $\begin{array}{c}\text { Average } \\
\text { Speed } \\
(\mathrm{kph})\end{array}$ & $\begin{array}{c}\text { Average } \\
\text { Daily } \\
\text { Distance } \\
(\mathrm{km})\end{array}$ & $\begin{array}{c}\text { Average } \\
\text { Time } \\
\text { Moving } \\
(\mathrm{hrs})\end{array}$ & $\begin{array}{c}\text { Average } \\
\text { Temp. } \\
(\mathrm{C})\end{array}$ & $\begin{array}{c}\text { Average } \\
\text { Idle } \\
\text { Time } \\
(\mathrm{hrs})\end{array}$ & $\begin{array}{c}\text { Average } \\
\text { Stops per } \\
\text { km }\end{array}$ \\
\hline León Route 1 & 15.5 & 166.5 & 7.34 & 20.6 & 3.4 & 3.4 \\
\hline León Route 2 & 17.9 & 182.4 & 7.09 & 19.9 & 3.1 & 2.9 \\
\hline Mexico City & 9.1 & 138.8 & 7.25 & 18.8 & 7.2 & 5.9 \\
\hline
\end{tabular}

Table 1. CDMX and León Bus Route Tracking. Adapted from MLED and NREL presentation, 2018

\section{Results}

Frequent stops and slow travel speeds make Mexico City and León transit bus routes conducive for electrification. In fact, bus routes in these Mexican cities are more aggressive (as measured by vehicle kinetic intensity) than U.S. observed routes (Figure 5). Kinetic intensity is the ratio of power-for-acceleration to powerfor-drag and is derived from speed and acceleration. This is an important metric used to evaluate the degree of stop-and-go driving. Regenerative breaking in BEBs will convert the loss of kinetic energy during deceleration back into the vehicle's battery as stored energy for acceleration instead of using its own energy reserves; thus, higher kinetic intensity indicates more stop-and-go driving and, therefore, greater opportunity for electrification. The analysis also demonstrated that BEBs were found to be between 2.5 and 5 times more efficient (in terms of $\mathrm{km} / \mathrm{L}$ ) than their diesel counterparts along the routes modeled and produced significantly lower total greenhouse gas emissions (both from the tailpipe and accounting for electricity production) (Figures 6 and 7). Higher efficiencies were observed in Mexico City as a result of the slower speeds and traffic that caused the conventional buses to have low fuel economy.

Modeling demonstrated that León's routes would require a larger battery than the Mexico City routes due to the longer daily distances and higher driving speed. Nonetheless, vehicle and battery technologies required to serve both Mexico City and León routes are currently commercially available.

\section{Implementation Considerations}

\section{BEBs are sensitive to extreme} temperatures, aggressive driving, high speeds, and passenger loads. Transit agencies typically implement electric buses in a pilot phase to understand how real-world conditions affect performance. Transit agencies and other stakeholders in CDMX and León must consider key factors 


\section{Key Results of BEB Technical Evaluation for Mexico City and León, Mexico}

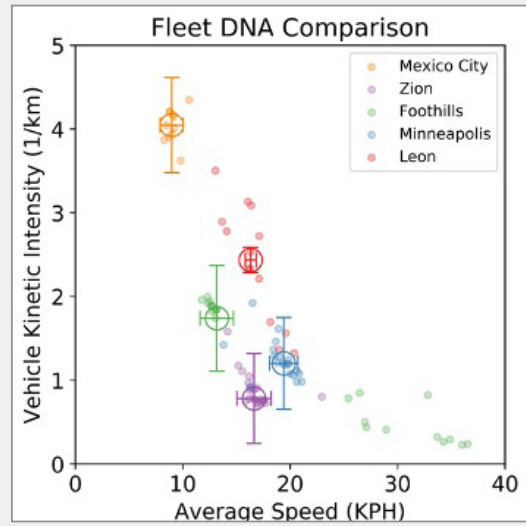

Figure 5. Kinetic intensity of evaluated bus routes in Mexico City and León compared to three U.S.-based routes (West Covina, California (Foothills), Minneapolis, Minnesota, and Zion National Park, Utah)

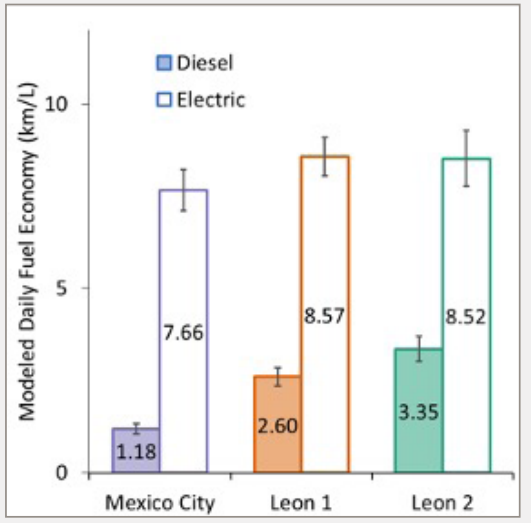

Figure 6. Modeled daily fuel economy $(\mathrm{km} / \mathrm{L})$ of diesel and electric buses in evaluated routes in Mexico City and León

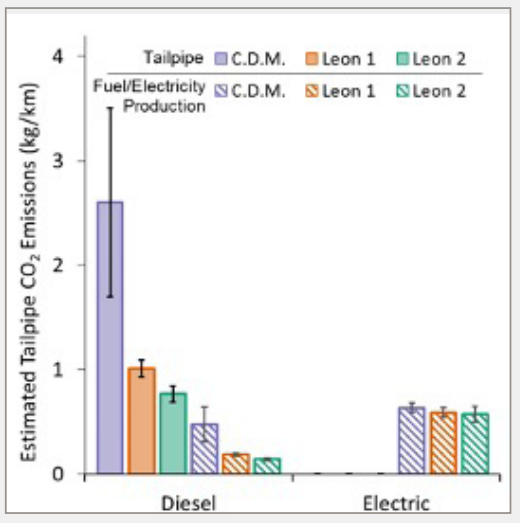

Figure 7. Estimated $\mathrm{CO}_{2}$ emissions from tailpipe and fuel/electricity production of diesel and electric buses in evaluated routes in Mexico City and León such as stakeholders' involvement during planning, driver training, and maintenance to optimally implement BEBs in their communities. Table 2 presents key topic areas and questions to consider when deploying BEBs.

\section{Conclusion}

NREL's analysis indicates that BEBs currently exists to fulfill the selected route requirements in $\mathrm{CDMX}$ and León while also producing fewer $\mathrm{CO}_{2}$ emissions than conventional diesel buses and using energy more efficiently. The slow speeds and frequent stops that characterize these three routes - which are quite common in other dense, congested cities worldwidemake them particularly conducive to electrification. While detailed analyses, such as those conducted for CDMX and León, are essential for understanding the technical feasibility of transit bus electrification, successful deployment of BEBs across Mexico and globally depends on evaluating other economic and institutional considerations that span the transportation and electricity sectors.
Table 2. Key Topic Areas and Considerations for Deploying BEBs

\section{\begin{tabular}{l|l} 
Considerations & Key Questions
\end{tabular}}

Operations

- Which routes are most suitable for BEBs?

- When will the buses charge (e.g., day, night)? Are additional buses needed to maintain operations?

- How will operators learn to drive BEBs? Will they need continual training?

- Will backup generators be necessary to maintain operability during power outages?

Charging Infrastructure

- Which charging strategy would work best? Plug-in at depot? On-route fast charge? Or a combination of both?

- Can the current utility grid meet the additional demand required by BEBs? How much power will the buses need? Are grid upgrades needed to accommodate electric bus fleets or can charging infrastructure provide grid benefits?

- Where are the best places to install chargers? Are there any space limitations? Should there be one charger for each bus, or one for multiple buses? Are on-route chargers needed?

Maintenance

- How will bus maintenance staff learn to handle repairs?

- Will special tools be needed for trouble shooting and diagnosing issues?

- What type of maintenance is required and how much does it cost?

Economic

- How do electricity rates (including demand charges) affect the charging costs? Is there an electric vehiclespecific rate? Can managed charging reduce charging costs and grid strain?

- Are there available incentives that reduce the costs of BEBs? 


\section{Additional Reading}

Eudy, Leslie, and Matthew Jeffers. "Foothill Transit Agency Battery Electric Bus Pr ogress Report.” Golden, CO: NREL. NREL/ PR-5400-73516. October 2019. https:// www.nrel.gov/docs/fy20osti/73516.pdf.

Greening the Grid. "Greening the Grid: Mexico.” https://greeningthegrid.org/wherewe-work/greening-the-grid-mexico.

NREL. "FASTSim: Future Automotive Systems Technology Simulator." Transportation Research. https://www.nrel.gov/ transportation/fastsim.html.

NREL. "Foothill Transit Electric Bus Evaluation." Transportation Research. https://www.nrel.gov/transportation/ fleettest-electric-foothill.html.

\section{References}

BNEF (BloombergNEF). "E-Buses to Surge Even Faster Than EVs as Conventional Vehicles Fade." May 21, 2018. https://about.bnef.com/blog/e-buses-surgeeven-faster-evs-conventional-vehiclesfade/.

Electric Vehicle Outlook 2020. 2020. https://about.bnef.com/electric-vehicleoutlook/.

C40 Cities. nd. "C40 : Green and Healthy Streets.” nd. https://www.c40.org/other/ green-and-healthy-streets.

ENCA (Estrategia Nacional de Calidad del Aire). National Air Quality Strategy. Secrettaria de Medio Ambiente y Recursos Naturales (SEMARNAT). May 2017. https://www.cccjac.org/uploads/9/1/9/2/91924192/semarnat_national_aq_strategy.pdf.

Eudy, Leslie, Robert Prohaska, Kenneth Kelly, and Matthew Post. Foothill Transit Battery Electric Bus Demonstration
Results. Golden, CO: NREL. NREL/TP5400-65274. January 2016. https://www. nrel.gov/docs/fy16osti/65274.pdf.

FTA (Foothills Transit Authority) and NREL. "King County Metro Battery Electric Bus Demonstration-Preliminary Project Results." Golden, CO: NREL. DOT/FTA-ZEB-FS1-May 2017. May 2017. https://www.nrel.gov/docs/fy17osti/68412.pdf.

Gobierno de la República de México. 2015. "Intended Nationally Determined Contribution." https://www4.unfccc.int/sites/ submissions/INDC/Published\%20Documents/Mexico/1/MEXICO $\% 20 I N D C \% 20$ 03.30.2015.pdf.

Hampel, Carrie. "63 Yutong Electric Buses for Mexico City." electrive.com. December 3, 2019. https://www.electrive. com/2019/12/03/63-yutong-electric-busesfor-mexico-city/.

ICCT (International Council on Clean Transportation). "Next Stop for Zero Emission Buses: Latin America." Washington, D.C.: ICCT. October 20, 2018. https:// theicct.org/news/next\%C2\%A0stop-zero-emission-buses-latin-america.

IEA (International Energy Agency). Global EV Outlook 2020. Paris, France: IEA. June 2020. https://www.iea.org/reports/global-ev-outlook-2020.

Janseen, Nicole A.H., Miriam E. Gerlofs-Nigland, Timo Lanki, Raimo O. Salonen, Flemming Cassee, Gerard Hoek, Paul Fishcer, Bert Brunekreef, and Mical Kryzyzanowski. Health Effects of Black Carbon. Copenhagen, Denmark: WHO Regional Office of Europe. 2012. http:// www.euro.who.int/_ data/assets/pdf file/0004/162535/e $\overline{96541 . p d f . ~}$

Li, Xiangyi, Camron Gorguinpour, Ryan Sclar, and Sebastian Castellanos. How to Enable Electric Bus Adoption in Cities
Worldwide. Washington, D.C.: World Resources Institute. May 2019. https://www. wri.org/publication/how-enable-electricbus-adoption-cities-worldwide.

Metrobús. "What is Metrobús?" 2020. https://www.metrobus.cdmx.gob.mx/dependencia/acerca-de. Accessed,

June 1, 2020.

NREL. "Future Automotive Systems Technology Simulator (FASTSim)." Golden, CO: NREL. NREL/FS-5400-71126. April 2018. https://www.nrel.gov/docs/fy18osti/71126.pdf.

Ritchie, Hannah, and Max Roxer. "CO and Greenhouse Gas Emissions." OurWorldInData.org. May 2017. https://ourworldindata.org/co2-and-other-greenhouse-gasemissions.

Secretaría de Medio Ambiente y Recursos Naturales de México. 2017. "Estrategia Nacional Calidad Del Aire.” https:// www.gob.mx/cms/uploads/attachment/ file/195809/Estrategia_Nacional_Calidad_del_Aire.pdf.

Sims R., R. Schaeffer, F. Creutzig, X. Cruz-Núñez, M. D’Agosto, D. Dimitriu, M.J. Figueroa Meza, et al. 2014: Transport. In: Climate Change 2014: Mitigation of Climate Change. Contribution of Working Group III to the Fifth Assessment Report of the Intergovernmental Panel on Climate Change. Cambridge University Press, Cambridge, UK. 2014. https:// www.ipcc.ch/site/assets/uploads/2018/02/ ipcc_wg3_ar5_chapter8.pdf.

UTM. "The Revival of the Emission-Free Trolleybuses in Mexico City." Urban Transport Magazine. August 14, 2019. https://www.urban-transport-magazine. $\mathrm{com} / \mathrm{en} /$ the-revival-of-the-emission-freetrolleybuses-in-mexico-city/.

\section{Written by Kamyria Coney, Karlynn Cory, Alexandra Aznar National Renewable Energy Laboratory}

\section{www.greeningthegrid.org | www.nrel.gov/usaid-partnership}

This work was authored, in part, by the National Renewable Energy Laboratory (NREL), operated by Alliance for Sustainable Energy, LLC, for the U.S. Department of Energy (DOE) under Contract No. DE-AC36-08GO28308. Funding provided by the United States Agency for International Development (USAID) under Contract No. IAG-17-2050 and by the United States Department of State (DOS) under Contract No. AC36-08GO28308. The views expressed in this report do not necessarily represent the views of the DOE or the U.S. Government, or any agency thereof, including USAID and the DOS.

Greening the Grid is a platform for expertly curated information, tools, and technical assistance to support countries in power system transformation and grid modernization. Greening the Grid is supported by the U.S. Agency for International Development.

The USAID-NREL Partnership addresses critical challenges to scaling up advanced energy systems through global tools and technical assistance, including the Renewable Energy Data Explorer, Greening the Grid, the International Jobs and Economic Development Impacts tool, and the Resilient Energy Platform. More information can be found at: www.nrel.gov/usaid-partnership.

USAID
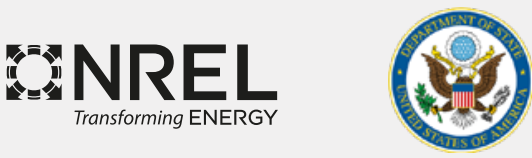